\title{
UN Guiding Principles at 10: Permeating Narratives or Yet Another Silo?
}

\author{
Nicola JÄGERST"
}

\begin{abstract}
The endorsement of the United Nations Guiding Principles on Business and Human Rights (UNGPs) triggered a remarkable process accelerating the recognition of human rights responsibilities for corporations in law and governance. Perhaps even more important is the emergence of an authoritative narrative on business and human rights (BHR), which arguably has the potential to overcome the often-fragmented approach to global issues. This article discusses the degree to which the BHR narrative has been able to penetrate competing powerful narratives that shape societal and regulatory responses. To what extent is the need to address the responsibility and accountability of corporations for human rights violations acknowledged? This is an especially pertinent question where it concerns imminent major global challenges such as climate change, which poses one of the greatest threats to human rights. Two major milestones of the last decade in the area of (environmental) sustainability are analysed: the Paris Climate Agreement and the Sustainable Development Goals. What role does the BHR narrative play in this context?
\end{abstract}

Keywords: narratives, Paris Climate Agreement, partnerships, Sustainable Development Goals, UNGPs

\section{INTRODUCTION}

The endorsement of the United Nations Guiding Principles on Business and Human Rights (UNGPs) ${ }^{1}$ by the Human Rights Council ten years ago has propelled the development of 'the business and human rights (BHR) movement'. The roots of the idea that corporations hold responsibilities for adverse human rights impacts stretch further back, though. Tragic, high profile examples of corporate misconduct such as the Bhopal disaster in 1984 or the Ogoni Nine executions in 1995 fuelled the quest for corporate accountability for human rights abuse. Subsequent development in law, regulation and governance was nevertheless relatively minor in light of the challenge

II Conflicts of interest: The author declares none.

* Professor, Tilburg University Law School, the Netherlands.

1 Human Rights Council, 'Guiding Principles on Business and Human Rights: Implementing the United Nations “Protect, Respect and Remedy” Framework', A/HRC/17/31 (21 March 2011).

Business and Human Rights Journal, 6 (2021), pp. 198-211 doi:10.1017/bhj.2021.9

under the terms of the Creative Commons Attribution-NonCommercial-NoDerivatives licence

(https://creativecommons.org/licenses/by-nc-nd/4.0/), which permits non-commercial re-use, distribution, and reproduction in any medium, provided the original work is unaltered and is properly cited. The written permission of Cambridge University Press must be obtained for commercial re-use or in order to create a derivative work. 
of closing the governance gap, the gap between the influence of corporations and the ability to regulate. The adoption of the UNGPs in 2011 is considered a game-changer. The UNGPs have accelerated developments in law and governance recognizing human rights responsibilities for corporations in an unprecedented manner. Norms in the UNGPs, such as human rights due diligence (HRDD), have found their way into regulation at the national, regional and international levels. For example, at the national level, an increasing number of countries have adopted National Action Plans on Business and Human Rights articulating how they will implement the UNGPs. ${ }^{2}$ Moreover, the UNGPs point the direction of future travel towards an increasing role for national law in this field, as can be witnessed by the growing body of laws on mandatory HRDD or elements thereof, such as disclosure and reporting. ${ }^{3}$ Moreover, there has been considerable uptake of the UNGPs at the regional level. ${ }^{4}$ For example, the European Union (EU) is working on legislation to make human rights and environmental due diligence in international supply chains mandatory for EU enterprises. ${ }^{5}$ At the international level, the UNGPs have found uptake in several international guidelines ${ }^{6}$ and there is the continuing work towards a BHR treaty. ${ }^{7}$

These developments are quite remarkable in light of the relatively short time that has passed since the adoption of the UNGPs. Yet, at the same time, it is easy to overstate the impact of the UNGPs. It has been pointed out that awareness of the UNGPs beyond the 'business and human rights-bubble' of consultants and academics working in this field, is quite low or uneven. ${ }^{8}$ The spill-over from soft law instruments into hard law is an

\footnotetext{
2 At the time of writing, 25 countries have adopted such a policy document. Danish Institute for Human Rights, www.globalnaps.org (accessed 19 January 2021).

3 These include laws from France (general human rights due diligence) and the Netherlands (due diligence relating to child labour). The consequences for not complying with these laws include civil liability claims and/or fines. The EU is currently working on a mandatory due diligence law on human rights and the environment. In other jurisdictions, laws have been adopted relating to certain aspects of HRDD, e.g., disclosure relating to human trafficking or slavery (California, the United Kingdom and Australia).

4 For example, the EU undertook steps to support the implementation of the UNGPs in its 2011 Communication on Corporate Social Responsibility, and in 2014 the Council of Europe issued a Declaration on the UNGPs, followed in 2016 by the Recommendation CM/Rec (2016)3 of the Committee of Ministers of the Council. In these documents, Member States are encouraged to implement the UNGPs. Furthermore, the Organization of American States has adopted resolutions in 2012 and in 2014 pointing out the importance of the UNGPs. Support for the UNGPs has also been expressed by representatives of the ASEAN (Association of Southeast Asian Nations) Intergovernmental Commission on Human Rights.

5 See the work plan of the European Commission for 2021, Brussels, 19.10.2020 COM(2020) 690 final, https:// ec.europa.eu/info/sites/info/files/2021_commission_work_programme_annexes_en.pdf (accessed 30 January 2021).

6 Since 2011, business responsibility to respect human rights has been integrated into numerous guidance documents for multinational corporations including: the Organization for Economic Co-operation and Development Guidelines for Multinational Enterprises, and the International Finance Corporation's Sustainability Performance Standards.

7 For an overview of this process, see 'Open-ended intergovernmental working group on transnational corporations and other business enterprises with respect to human rights', https:/www.ohchr.org/EN/HRBodies/HRC/WGTransCorp/ Pages/IGWGOnTNC.aspx (accessed 21 January 2021).

8 See, for example, Jolyn Ford, 'Business and Human Rights: Bridging the Governance Gap' (2015), https:// www.researchgate.net/publication/283663635_Business_and_Human_Rights_Bridging_the_Governance_Gap (accessed 21 January 2021). Ford cautions for overstating the levels of awareness and activity around the UNGPs. He points out the slow and piecemeal developments and at times contradictory patterns of activity and apathy. The UN Working Group has also pointed out that many corporations remain unaware, unable or unwilling to implement HRDD. Report of the Working Group on the issue of human rights and transnational corporations and other business enterprises, 'Corporate human rights due diligence - emerging practices, challenges and ways forward', A/73/163 (16 July 2018), para 93.
} 
embryonic development. Many developments are either small scale, in their infancy or, as some human rights advocates argue, have yielded disappointing results from the perspective of holding corporations accountable for human rights violations and providing victims with access to an effective remedy.

Perhaps more important than the at times slow or uneven developments in law and regulation is the fact that the UNGPs provide a 'lingua franca', a common language embraced by both private and state actors enabling a dialogue on BHR. Arguably, as suggested by Rees, with the adoption of the UNGPs, BHR has moved from a 'language' and has emerged as a 'narrative'. ${ }^{9}$ This narrative offers 'an organizing and explanatory or justificatory framework for [subsequent] initiatives'. ${ }^{10}$ According to Rees, the UNGPs provide 'normative legitimacy', and the narrative drives 'convergence and coherence' creating much greater momentum behind changes in business practice.' ${ }^{11}$ The term 'narrative' means different things in different disciplines. According to the Cambridge Dictionary, a 'narrative' is a particular way of explaining or understanding events. ${ }^{12}$ Like Rees, this article applies this understanding of the term narrative. It is used to refer to the degree to which the UNGPs (or elements thereof) are applied in subsequent developments that can potentially accelerate change. Narratives can influence, shape and validate societal developments. ${ }^{13}$ Despite the apparent global acceptance of the UNGPs as a normative reference point on acceptable corporate behaviour, the crucial question remains whether they are able to sufficiently permeate the critical discussions addressing the global challenges of our time. Certain contemporary challenges, such as climate change, pose such a threat to human rights, in fact an existential threat to humankind, that urgent action is needed. It is vital that a responsible role for corporations and their impact on human rights are not overlooked.

It is against this background that this article discusses the degree to which the UNGPs, and the BHR narrative that has emerged, have been able to penetrate competing powerful narratives. The previous decade saw not only the emergence of the BHR narrative but also the further development of other, influential narratives that speak to certain constituencies on various issues of global concern such as inequality, sustainability or the environment. Such narratives carry 'increasing influence in policy-making and standard-setting ${ }^{14}$ yet seem to develop largely in isolation and compete for attention of policymakers. The normative success of the UNGPs depends on the extent to which they succeed in permeating other influential narratives, aligning different policy areas that are currently often addressed in isolation. As will be discussed, Rees (and others) argue that the BHR narrative has 'tremendous strength' to permeate, strengthen and enrich other powerful narratives. ${ }^{15}$ The focus of this article is on the narrative of (environmental) sustainability.

\footnotetext{
9 Caroline Rees, Transforming How Business Impacts People: Unlocking the Collective Power of Five Distinct Narratives (Shift and Harvard Kennedy School, 2020).

10 Ibid, 1.

11 Ibid.

12 Cambridge Dictionary online, 'Narrative', https://dictionary.cambridge.org/dictionary/english/narrative (accessed 6 March 2021).

13 Rees, note 9, 1.

14 Ibid, 2.

15 Ibid, 1.
} 
After discussing what is meant by the BHR narrative, the fragmented approach towards issues of global concern and the potential role of the BHR narrative is addressed in section II. The article then turns to the issue of climate change and sustainable development and the accompanying narratives that have further developed in the previous decade in this area in parallel to the BHR narrative. The impact of corporations on human rights in the context of climate change and sustainability requires attention. The aim of this article is to see whether traces of the BHR narrative can be found in these competing narratives. ${ }^{16}$ This is done by exploring two major instruments adopted in the previous decade that have given further profile to the narrative of (environmental) sustainability. In section III, the 2015 Paris Agreement under the United Nations Framework Convention on Climate Change (Paris Climate Agreement) ${ }^{17}$ and the role of the BHR narrative is addressed. Section IV turns to the 2030 Agenda that launched the Sustainable Development Goals (SDGs). The question is addressed what role the BHR narrative plays in the SDGs. The analysis reveals little evidence that states have taken the BHR narrative on corporate responsibility and accountability as normative guidance in drawing up these documents. It is concluded that despite the apparent success of the UNGPs, old habits die hard and there is a risk of perpetuating old narratives when it comes to the role of BHR.

\section{The Business and Human Rights Narrative in a Fragmented Landscape}

With the adoption of the UNGPs, the 'decade of BHR' has accelerated and gained sharp profile. ${ }^{18}$ Several features set BHR apart from other approaches to the responsibility of corporations such as corporate social responsibility (CSR). ${ }^{19}$ Importantly, BHR shifts the discourse away from corporate philanthropy - the positive contribution that corporations can make to people's lives - to mitigating, preventing and remediating adverse human rights impacts of corporate activities. Corporate responsibility and accountability are thus at the core of BHR. A distinguishing feature of BHR is the development of standards, such as the UNGPs. ${ }^{20}$ The UNGPs, and elements thereof, have gained traction and arguably we are seeing the emergence of a BHR regulatory regime, although the process is slow and uneven. However, perhaps more important is the narrative that has emerged and grown since the adoption of the UNGPs and its potential to influence

\footnotetext{
16 The analysis in this article is 'one-way traffic': what does the BHR narrative bring to other narratives, in particular to the narrative of (environmental) sustainability? An interesting question that, due to space constraints of this article, cannot be addressed here is what other narratives could bring to the field of BHR. As will be discussed below (see text accompanying footnote 36), there is increasing recognition of climate change as part of corporate HRDD.

17 UN Framework Convention on Climate Change (UNFCCC) 31 ILM 849 (1992); Paris Agreement, Decision 1/CP.21, 'Adoption of the Paris Agreement', UN Doc FCCC/CP/2015/10/Add.1 (2015), annex.

18 For an analysis of this development, in comparison of what he calls the Business or Human Rights Era and the Business of Human Rights Era, see Surya Deva, "From "business or human rights" to "business and human rights": what next?' in Surya Deva and David Birchall (eds.) Research Handbook on Human Rights and Business (Edward Elgar Publishing, 2020) 1.

19 Anita Ramasastry, 'Corporate Social Responsibility versus Business and Human Rights: Bridging the Gap between Responsibility and Accountability’ (2015) 14 Journal of Human Rights 237.

20 Deva, note 18, 3.
} 
different narratives and approaches to global problems. The tendency to address such issues in isolation, with little to no interaction between regimes and policy areas, is well known. This problem of fragmentation of normative and institutional activity is mostly discussed from the perspective of international law. ${ }^{21}$ It has been suggested that the design and language of the UNGPs have the potential to break down silos and fragmented responses. ${ }^{22}$ Ruggie points out that the idea behind the UNGPs rests on 'the distributed network approach' rather than relying exclusively on top-down UN processes. This, according to Ruggie, is an important explanation of the success of the UNGPs as it has "triggered a process of "norm-cascading" well beyond their institutional sphere of origin'. ${ }^{23}$ The driving assumption behind the UNGPs is that compliance results primarily from persuasion, socialization and ultimately internalization rather than through coercion through law. ${ }^{24}$ These processes are intimately linked with language. The process towards the UNGPs created a shared narrative across different communities, neutralizing a lot of dissent and critique, which paralysed previous initiatives. The choice of language has contributed to the diplomatic success of the UNGPs. ${ }^{25}$ The use of (elements of) the BHR narrative across domains may be seen as a reflection of the degree of socialization and internalization, which ultimately may help guide policy responses towards a universalistic notion of BHR.

In parallel to the emergence of the BHR narrative, other existing and new narratives compete for influence. The question is whether the BHR narrative, especially its emphasis on the responsibility and accountability for adverse human rights impacts, in fact is permeating other competing influential narratives that shape societal and regulatory responses. Or does the BHR movement run the risk of heading towards becoming too much 'a world of its own', a too isolated narrative resulting in yet another silo in law, regulation and governance with too little interaction with crucial other regimes?

The decade that saw the adoption of the UNGPs also witnessed two other, interwoven narratives gaining further profile with the adoption of two global instruments. ${ }^{26}$ In 2015 , 196 states adopted the latest global instrument aimed at combating the existential threat of climate change: the Paris Climate Agreement. In the same year, 'Transforming our

\footnotetext{
21 International Law Commission, 'Fragmentation of international law: difficulties arising from the diversification and expansion of international law', A/CN.4/L.682 (13 April 2006).

22 This potential of the UNGPs is stressed by Margaret Wachenfeld, 'Connecting the climate change and business and human rights agendas', IHRB Briefing (8 December 2020), https://www.ihrb.org/focus-areas/just-transitions/briefingconnecting-climate-change-business-human-rights-agendas (accessed 30 January 2021). See also Rees, note 9.

23 John G Ruggie, 'The Social Construction of the UN Guiding Principles on Business and Human Rights', Corporate Responsibility Initiative Working Paper No. 67 (August 2017), https://www.hks.harvard.edu/research-insights/ publications?f\%5B0\%5D=publication_types\%3A121 (accessed 30 January 2021) 21.

24 See Tara J Melish and Errol Meidinger, 'Protect, Respect, Remedy and Participate: "New Governance” Lessons for the Ruggie Framework', in Radu Mares (ed.), The UN Guiding Principles on Business and Human Rights: Foundations and Implementation (Martinus Nijhoff Publishers, 2011) 303, 309. On his social constructivist approach, see John Gerard Ruggie, 'What makes the World Hang Together? Neo-Utilitarianism and the Social Constructivist Challenge' (1998) 52 International Organization 855, 869.

25 Christine Parker and John Howe 'Ruggie's Diplomatic Project and its Missing Regulatory Infrastructure', in Mares, note 24, 285.

26 The global challenges are many (inequality, new technology, etc.) and so are the distinct narratives that have emerged to address them. In this article, the focus is on climate change and sustainability.
} 
World: The 2030 Agenda for Sustainable Development' with the 17 SDGs was adopted. ${ }^{27}$ The 2030 Agenda is a call to action for the international community to advance peace and prosperity for people and the planet. The SDGs aim to end poverty, which must go hand in hand with strategies that improve health and education, reduce inequality, and spur economic growth - all while tackling climate change and working to preserve oceans and forests. The narratives surrounding climate change and sustainable development have proven influential, gaining traction in the international community of states, international organizations and the private sector. The question further explored below is to what extent a responsible role of corporations in light of adverse impact on human rights, the core of the BHR narrative, plays a role in these two major milestones of the (environmental) sustainability narrative: the Paris Climate Agreement and the SDGs.

\section{The Paris Climate Agreement and the Business and Human Rights NarRative}

To address the imminent dire implications of climate change for people and the planet, an elaborate legal regime has evolved. Central to this is the 1992 UN Framework Convention on Climate Change, followed by the Kyoto Protocol in 1997. The most recent global effort is the 2015 Paris Agreement, which creates an international legal regime to be implemented from 2020 onwards, with the goal of progressively reducing greenhouse gas emissions and enhancing the capacity of economies and communities to adapt to climate impacts.

Before analysing the role of the BHR narrative in the Paris Climate Agreement, the link between climate change and human rights more generally and, subsequently, the role of corporations and the UNGPs are briefly addressed.

It is clear that the consequences of climate change, such as severe weather events, floods, droughts, and food and water scarcity, are already negatively affecting the present generation and will continue to impact on the rights of future generations. Moreover, the necessary mitigation and adaptation measures can also have an adverse impact on human rights. ${ }^{28}$ While the impact of climate change on human rights is increasingly clear, a human rights law approach to climate change is not that straightforward. Certain characteristics of human rights law such as its state-centric focus, the continuing controversy of the extraterritorial reach of state duties and the micro-approach in the context of systemic processes and issues of causation present challenges to a human rights approach to climate change. Notwithstanding the complexities, it is clear that climate change is a human rights issue and over the past few decades, a human rights approach has slowly been included in the climate change regime. The preamble of the Paris Climate Agreement calls on parties to respect, promote and consider their human rights

\footnotetext{
27 United Nations General Assembly, 'Transforming Our World: The 2030 Agenda for Sustainable Development', Resolution 70/1, A/RES/70/1 (25 September 2015).

28 Report of the Office of the High Commissioner for Human Rights on the Relationship between Climate Change and Human Rights, A/HRC/10/61 (2009).
} 
obligations when taking climate action. ${ }^{29}$ The reference ended up in rather soft language in the preamble, but this development is significant nonetheless. The explicit reference to human rights makes the Paris Climate Agreement the first global environmental agreement confirming the international community's recognition that human rights obligations apply in the context of climate change. ${ }^{30}$

The Paris Climate Agreement stresses the intrinsic relationship that climate change actions, responses and impacts have with sustainable development for all in an unequal world and the eradication of poverty. ${ }^{31}$ The Agreement also points out the importance of protecting people and vulnerable groups in the context of adaptation measures. As pointed out by Duyck, such 'references provide an opportunity to implement the Paris Agreement while taking into account other rights-related objectives defined by the international community such as those related to 2030 Agenda and the SDGs'. ${ }^{32}$

Before discussing if and to what extent the UNGPs are taken into account in the Paris Climate Agreement, the role of corporations in the context of climate change requires some further exploration. Corporations are critical actors in addressing climate change. On the one hand, corporate activities drive climate change. Just 100 businesses (known as 'carbon majors') are responsible for 71 per cent of industrial greenhouse gas emissions since $1988 .^{33}$ In addition, other corporate activity such as deforestation or mining contributes to climate change that in turn can generate negative human rights impacts. Moreover, the need to address the threat of climate change has created new business opportunities for innovative industries, which are less carbon intensive and crucial to reach the goals set. The booming renewable energy industry has faced increasing scrutiny for lack of respect for human rights. It is feared that the rush towards a net zero carbon future will come at the expense of the vulnerable. A recent report shows the impact of the renewable industries on, among others, land rights, right to health and indigenous rights. ${ }^{34}$ As pointed out in this report, it is crucial that states set out clearly the

\footnotetext{
29 Paragraph 11 reads: 'Acknowledging that climate change is a common concern of humankind, Parties should, when taking action to address climate change, respect, promote and consider their respective obligations on human rights, the right to health, the rights of indigenous peoples, local communities, migrants, children, persons with disabilities and people in vulnerable situations and the right to development, as well as gender equality, empowerment of women and intergenerational equity.'

30 For a discussion of the inclusion of a human rights reference in the Paris Agreement, the preceding debate and its importance, see Sebastien Duyck, 'The Paris Climate Agreement and the Protection of Human Rights in a Changing Climate', in Bharat H Desai et al (eds.) Yearbook of International Environmental Law, vol 26 (Oxford: Oxford University Press, 2015) 3-45.

31 Paris Climate Agreement, Preamble, para 8.

32 Duyck, note 30,14. Analysis of subsequent practice shows, however, that a lot remains to be done to put this aspiration into practice. Sebastien Duyck et al, 'Human Rights and the Paris Agreement's Implementation Guidelines: Opportunities to Develop a Rights-based Approach' (2018) 12:3 Carbon \& Climate Law Review 191-202.

33 Richard Heede, 'Tracing Anthropogenic Carbon Dioxide and Methane Emissions to Fossil Fuel and Cement Producers, 1854-2010' (2014) 122 Climatic Change 229.

34 Business and Human Rights Center, Renewable Energy \& Human Rights Benchmark: Key Findings from the Wind \& Solar Sector (2020), https://media.business-humanrights.org/media/documents/files/Renewable_Energy_ Benchmark_Key_Findings_Report.pdf (accessed 21 January 2021). Since 2010, the BHRRC has identified 197 allegations of human rights abuses related to renewable energy projects. Abuse allegations include killings, threats and intimidation; land grabs; dangerous working conditions and poverty wages; and harm to indigenous peoples' lives and livelihoods. Allegations have been made in every region and across each of the five sub-sectors of renewable energy development: wind, solar, bioenergy, geothermal and hydropower.
} 
expectation that these corporations will live up to the responsibility to respect human rights as laid down in the UNGPs.

The UNGPs do not explicitly address climate change but clearly are relevant to climate mitigation efforts on the part of states, businesses and other stakeholders. ${ }^{35}$ According to the Office of the High Commissioner of Human Rights (OHCHR), human rights obligations of states in the context of climate change also involve the obligation to regulate business activities, implying that states must 'take adequate measures to protect all persons from human rights harms caused by business activities and, where such harms do occur, ensure effective remedies'. ${ }^{36}$ Thus, as part of Pillar I duty under the UNGPs, states would be expected to take a range of effective measures to protect against business-related climate change within their territory and/or jurisdiction. In addition to the obligations of states to prevent harm when taking climate action, the private sector responsibility to respect human rights under the UNGPs also applies in the context of climate change and sustainable development. There is growing recognition that climate change-related human rights impacts are a necessary dimension of the HRDD processes that businesses are required to put in place in order to fulfil their responsibility to respect. ${ }^{37}$

In sum, states and corporations bear human rights duties and responsibilities respectively in the context of climate change in accordance with the UNGPs. This, however, is not reflected in the Paris Climate Agreement. The Agreement includes a reference to human rights in general, but no reference is made to the responsibilities of business for human rights or the UNGPs. ${ }^{38}$ The perspective towards the private sector is one of partnership. Commitment of the private sector is critical for mobilizing the vast financial resources and providing the technological innovations needed to meet the goals set. ${ }^{39}$ However, as discussed above, corporate involvement in mitigation and adaption measures to address climate change can have an adverse impact on human rights. The

35 See Stefanie Richard Roos, 'Çlimate Change and Human Rights: What Follows for Corporate Human Rights Responsibility?', in Oliver C Ruppel, Christian Roschmann and Katherina Ruppel-Schlichting (eds.), Climate Change, International Law and Global Governance (Baden-Baden, Nomos, 2013) 299.

36 OHCHR, 'Understanding Human Rights and Climate Change' (2015) 3. OHCHR, 'Key Messages on Human Rights and Climate Change', para 8, https://www.ohchr.or/ocument/ssue/limateChang/eyMessages_on_HR_CC.pdf (accessed 15 January 2021).

37 European Commission (EC), 'Study on Due Diligence Requirements through the Supply Chain' (2020) 185, https:// op.europa.e//ublication-detai//publicatio/ba0a8fd-4c83-11ea-b8b7-01aa75ed71a/anguage-en (accessed 15 January 2021). For corporate responsibility for climate change, see Kristian Høyer Toft, 'Climate Change as a Business and Human Rights Issue: A Proposal for a Moral Typology' (2020) 5 Business and Human Rights Journal 1-27. For an analysis of the emerging notion of climate due diligence and the recent litigation before domestic courts, Chiara Macchi, 'The Climate Change Dimension of Business and Human Rights: The Gradual Consolidation of a Concept of "Climate Due Diligence"' (2021) 6 Business and Human Rights Journal 93. In 2015, a group of legal experts adopted the so-called 'Oslo Principles on Global Obligations to Reduce Climate Change' which also recognize that legal responsibility for climate change does not only rest with states but also 'enterprises' referencing the UNGPs, https://globaljustice.yale.edu/ sites/default/files/files/OsloPrinciples.pdf (accessed 21 January 2021).

38 Despite the fact that throughout the negotiation process the importance of the contribution of non-state actors was emphasized. Meinhard Doelle, 'The Paris Agreement: Historic Breakthrough or High Stakes Experiment?' (2016) 6:1 Climate Law 1.

39 'Large scale mobilization is necessary: global investments in infrastructure needs to increase from USD 3.4 trillion per year today to USD 6 trillion per year on average during the next 15 years. The incremental up-front investment cost of zero-GHG and climate-resilient infrastructure adds $5 \%$ of the total investment needed, but is necessary to ensure inclusive and sustainable growth'. Duyck, note 32 , footnote 168. 
responsibility of corporations for such impact is not addressed. The emphasis on the voluntary role of private sector actors has raised serious concerns among civil society groups. ${ }^{40}$ Concerns were expressed that certain projects and initiatives with notorious environmental and human rights records are not scrutinized. As aptly put by Duyck:

the necessity to act in order to reduce the causes and effects of climate change does not justify that response measures violate or threaten to violate the rights of the most vulnerable. As a consequence, policy choices regarding mitigation options must take into consideration adverse social impacts, such as threats to food security and the risk of land grabs. ${ }^{41}$

Duyck recommends that 'emerging efforts to incentivise and recognise voluntary actions by corporate actors should build on internationally agreed standards regarding the responsibility of the private sector for the protection of human rights' ${ }^{42}$ This, however, has not been the case. The Paris Climate Agreement does not refer to the UNGPs and it is therefore not surprising that the BHR narrative in subsequent practice since the adoption of the Paris Agreement seems largely absent.

At the same time, the Paris Climate Agreement has found quite some traction with the business community. Leading up to the adoption of the Agreement, coalitions of business and investors have pledged to reduce their carbon footprint and accelerate the transition to a low carbon economy. ${ }^{43}$ There has been a proliferation of voluntary and collaborative initiatives of various non-governmental actors, including business, aimed at helping achieve the goals of the Paris Climate Agreement. In 2016, at the 22nd session of the Conference of the Parties (COP 22), the so-called 'Marrakesh Partnership for Global Climate Action' was launched with the aim to formalize and further structure the many actions of non-governmental actors and linking these to other international agendas, in particular the SDGs. ${ }^{44}$ The Marrakesh Partnership does not address 'the importance of promoting the accountability of the participating actors with regards to human rights. Both the criteria included for the selection of projects and initiatives focus only on climate benefits and on transparency regarding these climate-related outcomes' ${ }^{45}$

Thus, in the context of the Paris Climate Agreement, there is no recognition of the need to ensure that corporations, which are incentivized through the international climate narrative, respect human rights standards in this process. The UNGPs, being the most authoritative statement on the responsibilities of corporations for human rights, 'could

\footnotetext{
40 Duyck, note 30, 37. On the danger of corporate capture of UN agencies and processes, see Deva, note 18, 6.

41 Duyck, note 30, 14.

42 Ibid.

43 See, for example, We Mean Business, 'The Business Brief: Shaping a Catalytic Paris Agreement', https:// www.wemeanbusinesscoalition.org/wp-content/uploads/2017/08/The-Business-Brief.pdf (accessed 21 January 2021). See also the Science Based Targets initiative (SBTi), https://sciencebasedtargets.org (accessed 22 February 2021). The latter initiative involving over 1,000 companies aims to drive 'ambitious climate action in the private sector by enabling companies to set science-based emissions reduction targets'. The website makes scant reference to CSR but not to human rights or the UNGPs.

44 UN Climate Change, 'Marrakech Partnership for Global Climate Action', https://unfccc.int/climate-action/ marrakech-partnership-for-global-climate-action (accessed 6 March 2021).

45 Duyck, note 30, 38.
} 
provide a useful tool to develop more stringent selection'. ${ }^{46}$ State reporting also does not reflect acknowledgement of the importance of corporate responsibility for human rights in this context. States are under the legal obligation to prepare, communicate and maintain the so-called Nationally Determined Contributions (NDCs) on the basis of successive five-year cycles. The importance of including the need for corporate respect for human rights in climate action in the NDCs has been pointed out. ${ }^{47}$ However, reference to BHR in the NDCs seems to be absent. ${ }^{48}$ In sum, the role envisioned for the private sector in the Paris Climate Agreement and subsequent documents and processes is one of partnership. The focus is on a voluntary contribution to achieving the aims of the Agreement bypassing any mention of the need to ensure a responsible and accountable role for corporations for adverse human rights impact in the context of climate change. The BHR narrative hardly seems to play a role so far.

\section{The Sustainable Development Goals and the Business AND Human Rights NaRRATIVE 49}

The last BHR decade saw the adoption of another influential global instrument. In 2015, the United Nations General Assembly adopted the 2030 Agenda for Sustainable Development. ${ }^{50}$ Building on the Millennium Development Goals (MDGs), the 2030 Agenda sets new goals aimed at mobilizing efforts to end all forms of poverty, fight inequalities and tackle climate change. The 2030 Agenda contains 17 SDGs and 169 targets. Moreover, a global indicator framework containing 230 indicators has been developed to measure progress. Compared with the preceding MDGs, the SDGs are more elaborate, addressing a wider scope of global challenges including climate change, and apply universally.

The 2030 Agenda and the SDGs have proven to be a successful narrative capturing the attention of many international organizations, states and other actors, including the human rights community. Arguably, the development of an extensive institutional apparatus to measure progress, adds to the appeal of the SDGs. The Global Compact, the UN's call for companies to align their operations with universal human rights, labour,

\footnotetext{
46 Ibid.

47 Business and Human Rights Resource Center, note 34.

48 Due to space constraints, a thorough analysis of all NDCs is not feasible in this article. It is clear nevertheless that while several, mostly developed countries do include human rights dimensions acknowledging the link between climate action and human rights in their NDCs (Duyck, note 32,10), developing countries seem less inclined to acknowledge the human rights dimensions in their NDCs. For example, an empirical study of 32 NDCs in the Asia Pacific Region found that only seven of these NDCs made direct references to human rights. None of these NDCs referred to human rights in the mitigation section. Pin Pravalprukskul et al, The Integration of Human Rights in the Nationally Determined Contributions in Asia-Pacific to the Paris Agreement on Climate Change (Raoul Wallenberg Institute \& Stockholm Environmental Institute, 2017), https://environmentalmigration.iom.int/sites/default/files/Human rights and NDC report.pdf (accessed 19 January 2021).

49 This section draws on the empirical research done for my article: N Jägers, 'Sustainable Development Goals and the Business and Human Rights Discourse: Ships Passing in the Night?' (2020) 42:1 Human Rights Quarterly 145. For that article, the first and second cycles of voluntary reporting by states where studied looking for traces of the BHR narrative.

50 United Nations General Assembly, 'Transforming Our World', note 27.
} 
environment and anti-corruption, offers an example of the appeal and influence of the SDG narrative. On the website and in the UN Global Compact's strategy for 2021-2023, the SDGs take centre stage. ${ }^{51}$ This raises the question to what extent this includes the BHR focus on responsibility for adverse human rights impact. In other words, what role does the BHR narrative play in the SDGs? To analyse this, first a brief discussion of the role of human rights in the SDGs in general is required before turning to the BHR dimension.

The goals set by the UN 2030 Agenda are ambitious and promise to 'leave no one behind'. There is quite some overlap between the aims of 2030 Agenda and human rights in this overall promise, in the references to human rights in the Agenda and in many of the targets that implicitly reflect human rights language. ${ }^{52}$ The goals themselves, however, do not explicitly refer to human rights. In fact, notwithstanding that there seems more convergence between human rights and sustainable development when compared with the MDGs, the connection between human rights and the SDGs is not that straightforward and requires critical assessment. ${ }^{53}$ Despite general references to human rights, the language in 2030 Agenda and the SDGs is largely non-committal and avoids recognition of responsibility and accountability for human rights. ${ }^{54}$ An important feature of the SDGs is that these goals explicitly recognize business as a key partner in realizing sustainable development. ${ }^{55}$ Involvement of the private sector is especially deemed crucial for raising the massive financial resources necessary to meet the goals set. ${ }^{56}$ Moreover, the SDGs foresee an important role for business in the areas of innovation and job creation. The role envisioned for business is most explicit under SDG 17 'Partnerships for the Goals'.

Thus, the 2030 Agenda and the SDGs recognize the private sector as a partner in achieving sustainable development, continuing an earlier development towards publicprivate partnership in the field of sustainable development. ${ }^{57}$ This raises the question if, or

51 UN Global Compact, 'UN Global Compact Strategy 2021-2023', https://www.unglobalcompact.org/what-is-gc/ strategy (accessed 22 February 2021). In a statement in 2015, the Global Compact acknowledges the importance of the BHR-dimension to the SDGs by publishing a statement in support of the UNGPs as 'a powerful and critical companion to the SDGs'. 'Business Community Affirms that Respect for Human Rights is a Key Contribution to Sustainable Development', https://d306pr3pise04h.cloudfront.net/docs/issues_doc\%2Fhuman_rights\%2Fbusiness-statementsupporting-GPs-SDGs.pdf (accessed 22 February 2021).

52 The Danish Institute for Human Rights (DIHR) claims that more than 90 per cent of the SDG targets are linked to international human rights and labour standards. See the tool developed by the DHRI linking the SDGs and human rights: http://sdg.humanrights.dk/en (accessed 5 January 2021).

53 For a discussion of the relationship between the SDGs and human rights, see Jägers, note 49, 150-155 and the references there to other critical scholarship on the relation between human rights and the SDGs.

54 On a fundamental level, it can be argued that it is troubling to converge goals with rights. As pointed out by Pogge and Sengputa 'the development goals discourse invites an incremental approach to overcoming deprivations. ... The human rights discourse, by contrast, suggests that deprivations must be ended right away'. Thomas Pogge and Mitu Sengupta, 'Assessing the Sustainable Development Goals from a Human Rights Perspective' (2016) 32 Journal of International and Comparative Social Policy 83, 83-4.

55 The 2030 Agenda states that it is necessary to involve the private sector 'ranging from microenterprises to cooperatives to multinationals'. United Nations General Assembly, 'Transforming Our World', note 27, para 67. The MDGs were criticized for not recognizing the role of the private sector.

56 UN General Assembly, 'Addis Ababa Action Agenda of the Third International Conference on Financing for Development', A/Res/69/313 (27 July 2015).

57 Public-private partnerships in the field of sustainable development can be traced back to the UN Summit in Johannesburg (2002) and the UN Conference on Sustainable Development (Rio +20). UN, 'A New Global Partnership: 
to what degree, the SDGs pay attention to the accountability dimension of involving corporations in reaching the SDGs. It is argued that tensions exist when turning to corporations to achieve the SDGs without acknowledging their possible complicity in creating some of the problems of sustainable development. ${ }^{58}$ To what extent is the negative impact that corporations can have on individuals and communities acknowledged in the SDGs?

An analysis of the 2030 Agenda shows that very little attention is given to the BHR narrative. ${ }^{59}$ The UNGPs are referred to only once in the 2030 Agenda, in paragraph 67 where it is stated that:

Private business activity, investment and innovation are major drivers of productivity, inclusive economic growth and job creation. [...] We call on all businesses to apply their creativity and innovation to solving sustainable development challenges. We will foster a dynamic and well-functioning business sector, while protecting labour rights and environmental and health standards in accordance with relevant international standards and agreements and other on-going initiatives in this regard, such as the Guiding Principles on Business and Human Rights. ${ }^{60}$

Scattered across the various targets there is some more implicit reference to a responsible role for business, albeit couched in terms such as 'ensuring sustainable consumption and production patterns' 61 or encouraging companies to adopt sustainable practice and integrating this sustainability information into reporting cycles. $^{62}$ Notably, in SDG 17 on Partnerships for the Goals and the accompanying targets, there is no reference to the responsibility of corporations or any other BHR language. Instead of referring to concepts of the BHR narrative, the 2030 Agenda and the SDGs include vague terminology where there is little common understanding of its meaning. An analysis of subsequent state reporting reveals very little evidence of the process of 'norm cascading'. ${ }^{63}$ Only a handful of European countries show a limited degree of internalization of the BHR narrative by explicitly including BHR language in their Voluntary National Reports submitted in the context of the Follow-up and Review Procedure. Most reports mention the more vague and broader notion of CSR instead of referring to the BHR narrative. Most national reports make no mention of the responsibilities of corporations in the context of the SDGs. The lack of attention for the BHR narrative in the context

\footnotetext{
Eradicate Poverty and Transform Economies through Sustainable Development' (2013), https:// sustainabledevelopment.un.org/content/documents/8932013-05\%20-\%20HLP\%20Report\%20-\%20A\%20New\% 20Global\%20Partnership.pdf (accessed 21 January 2021).

58 Regina Scheyvens, Glenn Banks and Emma Hughes, 'The Private Sector and the SDGs: The Need to Move Beyond 'Business as Usual' (2016) 24 Sustainable Development 371, 380.

59 Jägers, note $49,163-167$.

60 United Nations General Assembly, 'Transforming Our World', note 27, para 67.

61 Ibid, SDG 12.

62 Ibid, SDG target 12.6.

63 For a detailed analysis, see Jägers, note 49, 167-171.
} 
of their involvement in achieving the SDGs has not gone unnoticed and has given rise to concern within civil society ${ }^{64}$ and various UN human rights bodies. ${ }^{65}$

\section{Conclusion}

The endorsement of the UNGPs in 2011 triggered a process through which, in a relatively short period, a BHR narrative has emerged with corporate responsibility and accountability for adverse human rights impacts at its core. Acclaimed as the authoritative normative reference point for responsible corporate behaviour, the UNGPs have been embraced by many. The success of the UNGPs lies in a process of 'norm-cascading', influencing other powerful narratives that ultimately help shape policy responses. Arguably, the design and language of the UNGPs hold promise to penetrate the notoriously fragmented regulatory and policy responses to global problems and the incoherence that arises from such a siloed approach. Corporate (ir)responsible behaviour plays a significant role in many of the challenges faced today. In the critical area of climate change, this is certainly the case. Yet, the dimension of corporate responsibility and accountability for human rights is largely lost in the (environmental) sustainability narratives. The above brief exploration of the Paris Climate Agreement and the SDGs, two global instruments central to the narrative on (environmental) sustainability, reflect remarkably little uptake of the BHR narrative by states. Despite the central role of business in (the responses to) climate change, the need to address the responsibilities of corporations for adverse impacts on human rights in this context is hardly addressed. It is argued that the degree to which states adopt this narrative can be seen as a reflection of a process of internalization of BHR and the need to hold corporations responsible and accountable for human rights violations.

In general, it should be acknowledged that progress in achieving these outcomes in the BHR field itself remains wanting. Moreover, the fact that these global instruments do not mention corporate accountability for human rights does not mean subsequent practice might not broaden to include this dimension, as recent climate litigation might indicate. ${ }^{66}$ However, the lack of reference to corporate responsibility and accountability in competing narratives indicates that BHR to date does not seem to function as the guidepost for states on how to involve the private sector in reaching (environmental) sustainability goals in a manner that recognizes their human rights responsibilities. In

\footnotetext{
64 See, for example, Namit Agarwal, Uwe Gneiting and Ruth Mhlanga, 'Raising the Bar: Rethinking the Role of Business in the Sustainable Development Goals', Oxfam Discussion Paper (February 2017), https://www.oxfam.org/en/ research/raising-bar-rethinking-role-business-sustainable-development-goals (accessed 13 January 2021); Institute for Human Rights and Business, 'State of Play: Business and the Sustainable Development Goals. Mind the Gap challenges for implementation' (2015), https://www.ihrb.org/uploads/reports/2015-09\%2C_Report\%2C_State_of_Play_-Business_the_UN_Sustianable_Development_Goals_-_Full_Report.pdf (accessed 13 January 2021)

65 OHCHR, 'Integrating human rights into the post-2015 development agenda: follow-up and review: ensuring accountability for the SDGs, https://www.ohchr.org/Documents/Issues/MDGs/Post2015/ AccountabilityAndThePost2015Aagenda.pdf (accessed 13 January 2021); OHCHR, 'The Business and Human Rights Dimension of Sustainable Development: Embedding "Respect, Protect and Remedy" in SDGs Implementation' (30 June 2017), https://www.ohchr.org/Documents/Issues/Business/Session18/InfoNoteWGBHR_ SDGRecommendations.pdf (accessed 13 January 2021).

66 See Toft, note 37; Macchi, note 37.
} 
fact, the analysis in this article reveals the prevalence of perpetuating the CSR narrative of linking responsible business conduct to philanthropy. As Deva has pointed out, despite the continuing and ever more apparent negative impact of corporate conduct on human rights, most businesses are continuing with their leisurely 'human rights journey' and states often remain mute on the responsibilities of corporations. ${ }^{67}$ Moreover, "states continue to pursue a "development first, human rights later" strategy and "cashstrapped UN Agencies increasingly flirt with business to forge unprincipled partnerships", ${ }^{68}$ In light of the immense challenges and the need to mobilize vast resources, seeking the partnership of the private sector is a necessity, but this should not come at the expense of the vulnerable whose human rights are negatively affected by corporate activity.

67 Surya Deva, 'A Just Recovery for Whom? And How to Achieve It?' (8 January 2021), https://www.businesshumanrights.org/en/blog/a-just-recovery-for-whom-and-how-to-achieve-it/ (accessed 21 January 2021).

68 Ibid. 